\title{
CONDITIONING ELECTRONICS IN A SELF-POWERED VIBRATION REDUCTION SYSTEM: EXPERIMENTAL TESTING
}

\begin{abstract}
This paper summarises the results of laboratory testing of a vibration reduction system with energy harvesting capability, implemented in an 2-dof mechanical application. The vibration reduction system comprises of a commercially available RD-1005-3 type magnetorheological (MR) damper and an electromagnetic energy transducer (EPE) executing the reciprocating motion. The aim of the experiment was to compare the performance of the vibration reduction with two types of power conditioning systems and that in which the MR damper coil is fed directly with energy generated by EPE. Frequency characteristics are provided showing the plots of transmissibility coefficients, MR damper force, voltage generated by EPE, current intensity in the MR damper control coil, supplied electric power and mechanical power dissipated by the damper.
\end{abstract}

Keywords: vibration reduction system, MR damper, energy harvesting, energy conditioning

\section{ELEKTRONICZNY OBWÓD KONDYCJONOWANIA ENERGII \\ W SAMOZASILAJACCYM SIE UKEADIE REDUKCJI DRGAŃ: \\ BADANIA EKSPERYMENTALNE}

$W$ artykule przedstawiono wyniki badań laboratoryjnych ukladu redukcji drgań z odzyskiem energii, zastosowanego $w$ aplikacji mechanicznej o dwóch stopniach swobody (2-DOF). Rozważany układ redukcji drgań sktadal się z komercyjnego thumika magnetoreologicznego (MR) typu RD-1005-3 oraz elektromagnetycznego przetwornika energii drgań (EPE) o ruchu posuwisto-zwrotnym. Celem eksperymentów bylo porównanie skuteczności działania układu redukcji drgań przy zastosowaniu dwóch typów układów kondycjonowania energii do układu, w którym energia wytworzona przez EPE zasila bezpośrednio cewke tlumika MR. Przedstawione zostaly charakterystyki czestotliwościowe pokazujqce wspótczynniki przenoszenia drgań, sity wytwarzane przez tlumiki MR, napięcie wytwarzane przez EPE, natężenie pradu w cewce sterujqcej tlumika MR, dostarczanq moc elektrycznq oraz moc mechaniczna rozpraszanq przez thumiki.

Stowa kluczowe: układ redukcji drgań, thumik MR, odzysk energii, kondycjonowanie energii

\section{INTRODUCTION}

Vibration reduction systems incorporating MR dampers and utilising the electromagnetic methods of energy recovery (Cho et al. 2005, 2007, Sapiński 2011, Jastrzębski 2014) can effectively reduce the vibration of mechanical applications at near resonance frequencies. Besides, they do not require an external source of energy or energy storage strategy. Simulations of the energy balance (Snamina and Sapiński 2011) and experimental tests (Sapiński 2011, Jastrzębski 2014) reveal that the amount of energy recovered from mechanical vibration by EPE is sufficient to power supply the MR damper coil. When compared to semiactive vibration reduction systems utilising MR dampers, they do not require any additional sensors or controllers. EPE can be also integrated with a MR damper (Sapinski 2014), thus creating a self-powered electromechanical element dissipating the energy of vibration. A major drawback of such systems, however, is that vibration tends to be enhanced for frequencies higher than the resonance frequency. This problem can be solved by transforming the recovered energy before it is fed to supply the MR damper coil. There are two alternative methods of transforming electric power, the first method involves the control of current intensity in the MR damper coil in accordance with the selected algorithm (Sapiński 2011, Sapiński et al. 2011a, 2011b) whereby the coil is cyclically connected and disconnected to the electric power source (EPE). In the other solution a four-terminal network made of passive elements is provided between the EPE transducer coil and the MR damper coil. This study summarises the results of laboratory testing done on a vibration reduction system with energy harvesting capability in which the latter solution is applied.

\section{CONDITIONING SYSTEM}

The conditioning system incorporates a four-terminal network connected in between the EPE and MR damper coils. Its function is to transform (condition) energy recovered from mechanical vibration such that the performance of the vibration reduction system should be improved. Two types of conditioning systems are considered (fig. 1): one comprising a bi-sectional rectifier with a filtering condenser $4.7 \mathrm{mF}$ (SP MG) or a bipolar condenser with the capacity $4.7 \mathrm{mF}$ (SP C1) and $18.8 \mathrm{mF}(\mathrm{SP} \mathrm{C} 2)$.

\footnotetext{
* AGH University of Science and Technology, Department of Process Control, Krakow, Poland; lukasz.jastrzebski83@gmail.com
} 
a)

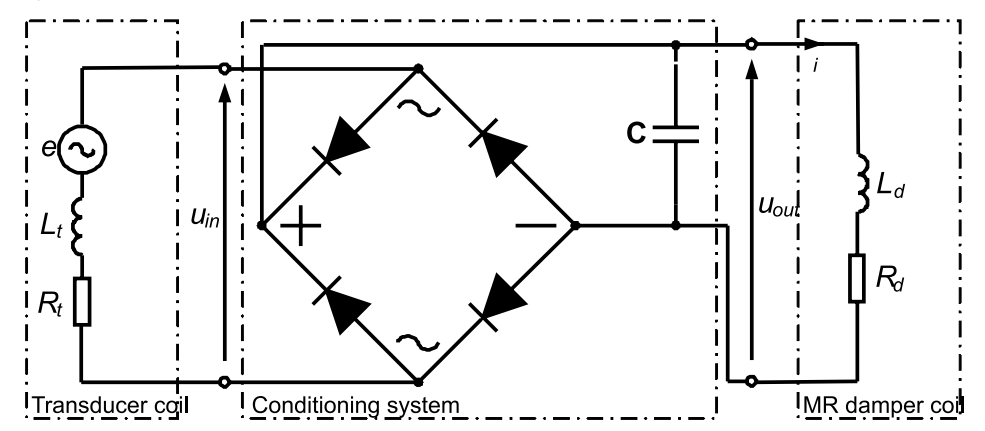

b)

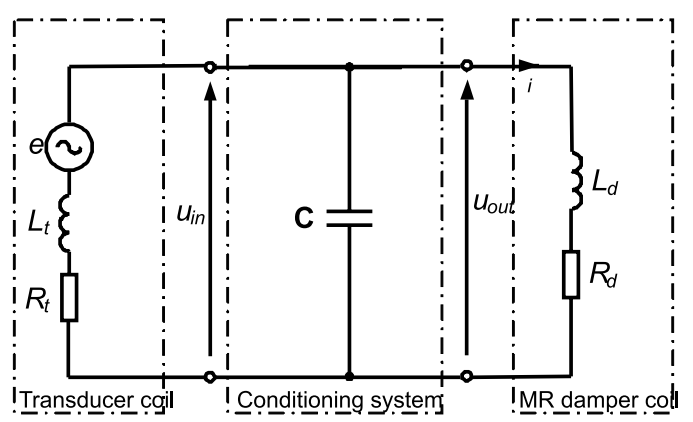

Fig. 1. Schematic diagram of the conditioning system comprising: a) a Greatz bridge, b) a bipolar condenser

A bi-sectional rectifier is structured as a Graetz bridge made of STPS2L40U - type Shottky's diodes ensuring that the forward voltage is twice as low as when silicone diodes are used.

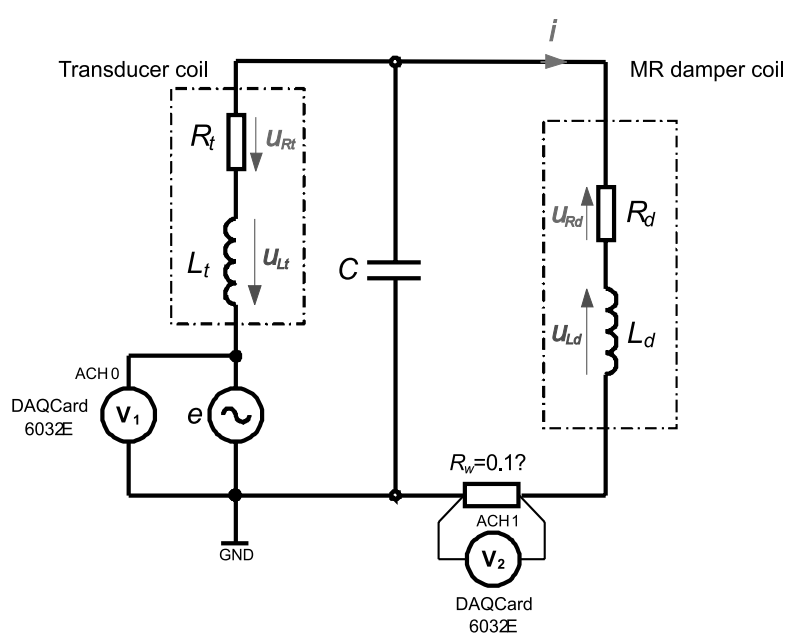

Fig. 2. Schematic diagram of the measurement circuit comprising an EPE coil, MR damper and a bipolar condenser

Figure 3 shows the frequency characteristics of an electric circuit comprising the connected transducer coil and MR damper coil and a bipolar condenser (SP C1, SP C2) and in which the coils are connected directly (SP).

a)

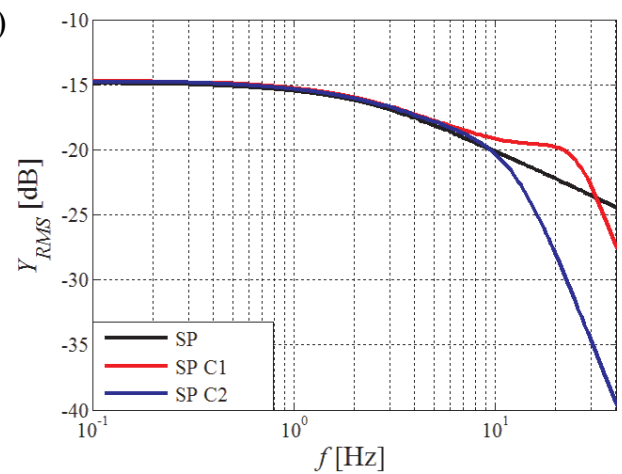

The schematic diagram of the measurement circuit is shown in figure 2, incorporating an external voltage source, an NI DAQCard 6032E measurement card (National Instruments 2015) and the current sensor based on a standard resistor $0.1 \Omega$ and an instrumentation amplifier AD620 (Analog Devices 2015). The card DAQCard 6032E enables the measurement of voltage $u_{\text {in }}$ generated by the external source and of current intensity $i$ in the damper coil with the sampling frequency $50 \mathrm{kHz}$.

Tests were conducted for the applied sine voltage with the amplitude $1 \mathrm{~V}$ and frequency varied in the range 0.1-40 Hz. Accordingly, we obtain the admittance $Y_{R M S}$ of the investigated circuit (equation (1)) and the phase shift $\varphi$ between current intensity $i$ and voltage $u_{i n}$ (equation (2)).

$$
Y_{R M S}=\frac{I_{R M S}}{U_{R M S}}=\frac{\sqrt{\frac{1}{T} \int_{t}^{t+T} i^{2}(t) d t}}{\sqrt{\frac{1}{T} \int_{t}^{t+T} u_{i n}^{2}(t) d t}}
$$

$$
\varphi=-\frac{\tau}{T} \cdot 360^{\circ}
$$

In the frequency range $0.1-7 \mathrm{~Hz}$ application of the conditioning systems SP C1 and SP C2 does not change

b)

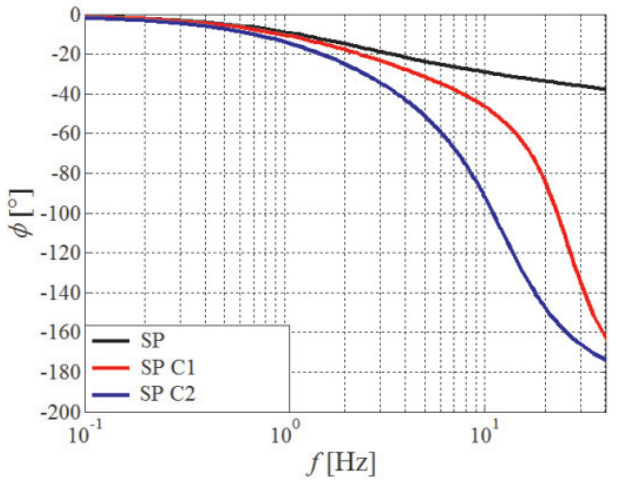

Fig. 3. Frequency characteristics of the transducer coil connected to the control coil in the damper RD-1005-3 and to the condensers: a) amplitude vs frequency, b) phase shift vs frequency 
the circuit's admittance $Y_{R M S}$ in comparison to SP. Admittance of the circuit SP C1 is higher than that of SP in the frequency range $7-30 \mathrm{~Hz}$ whilst for frequencies in excess of $30 \mathrm{~Hz}$ it gets lower. For frequencies higher than $7 \mathrm{~Hz}$, the admittance of SP C2 is lower than in the circuit SP. For frequencies in excess of $0.5 \mathrm{~Hz}$, the phase shift $\varphi$ in SP C1 and SP C2 is increased in relation to SP.

\section{LABORATORY SET-UP}

The schematic diagram of the laboratory set-up is shown in figure 4. Its key components include a vibration generation system and measurement system. The vibration generation system incorporates a shaker V780 power-supplied by an amplifier HPA-K (Brüel\&Kjær 2015), a power drive Dactron Laser USB and a piezoelectric acceleration meter 353B33 (PCB Piezotronics 2015). The vibration generation system is controlled via a PC supported with Dactron Shaker Control software. The general view of the laboratory set-up is shown in figure 5 .

The key components of the measuring system are: RT-DAC 4 PCI measurement card (Inteco 2015), three displacement sensors FT 50 RLA 70 (SensoPart 2015), a tensometric force sensor EMS (Emsyst 2015), a piezoelectric

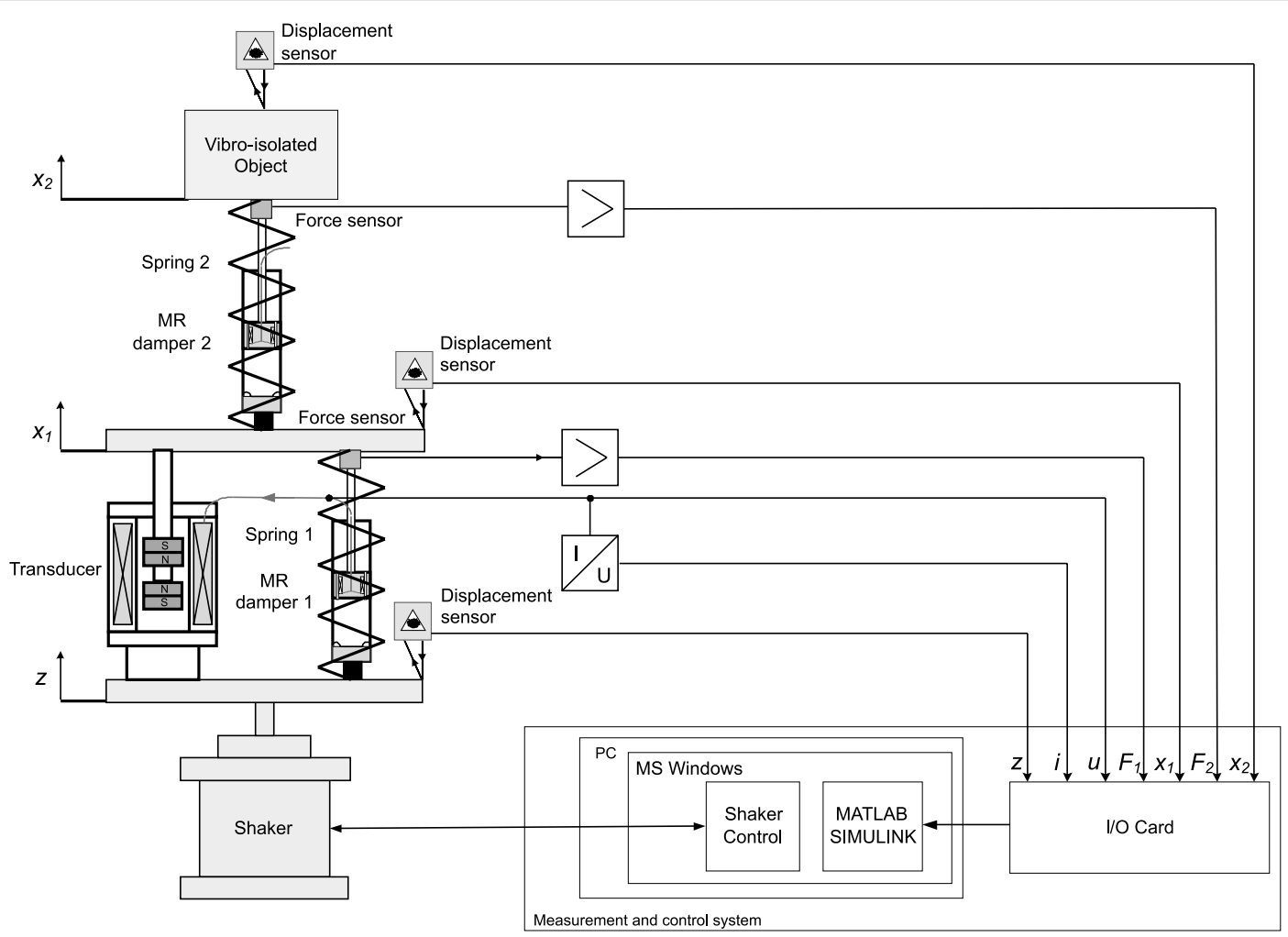

Fig. 4. Schematic diagram of the experimental set-up

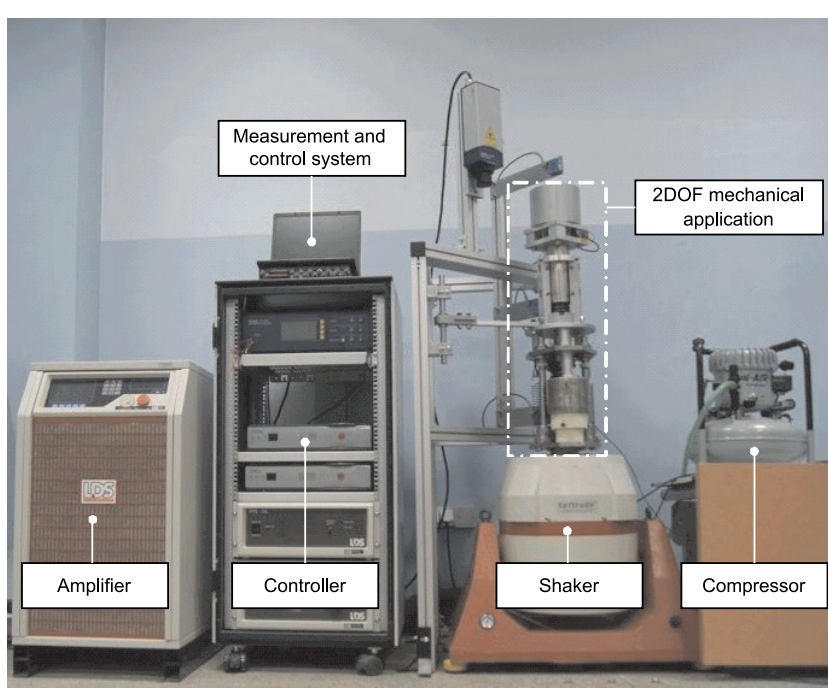

Fig. 5. Experimental set-up - general view 
force sensor 208-C03 with the signal conditioning unit 480B21 (PCB Peizotronics 2015) and a current sensor based on the standard resistor $0.1 \Omega$ and an instrumentation amplifier AD620 (Analog Devices 2015). The physical quantities registered by the measurement system include: displacement $z$ (excitation), displacement $x_{1}$ of the object with the mass $m_{1}$, displacement $x_{2}$ of the object with mass $m_{2}$, force $F_{T 1}$ generated by the damper MR1, force $F_{T 2}$ generated by the damper MR2, voltage $u$ across the transducer clamps (electromotive force e) and current intensity in the damper coils $i_{1}$ (MR1), $i_{2}$ (MR2). All measured quantities are converted into voltage signals in the range $\pm 10 \mathrm{~V}$ and sampled with frequency $1 \mathrm{kHz}$. The measurement card is supported by MATLAB/Simulink (version 2007b) with the installed toolbox RTCON (Inteco 2015).

\section{EXPERIMENTAL}

Experiments were conducted for the applied sine excitation $z(t)$ with amplitude $3.5 \mathrm{~mm}$ and frequency $f$ varied in the range $2-16 \mathrm{~Hz}$, with the step $0.25 \mathrm{~Hz}$. Signals were registered for $20 \mathrm{~s}$, the analysis is restricted to those registered over the last 10 seconds to eliminate the effects of transients. During the experiments the MR2 damper coil was supplied from an external source with the dc current $I_{2}=0.1 \mathrm{~A}$ and $I_{2}=0.3 \mathrm{~A}$, thus enabling a set damping level between the objects with the masses $m_{1}$ and $m_{2}$. The damper MR1, a component of the vibration reduction system, was supplied from an energy harvesting EPE. The values of the transmissibility coefficients $T_{x 1 z}$ and $T_{x 2 z}$ are obtained from equations (3) and (4).

$$
\begin{gathered}
T_{x 1 z}=\frac{X_{1 R M S}}{Z_{R M S}}=\frac{\sqrt{\frac{1}{T} \cdot \int_{t}^{t+T} x_{1}(t)^{2} d t}}{\sqrt{\frac{1}{T} \int_{t}^{t+T} z(t)^{2} d t}} \\
T_{x 2 z}=\frac{X_{2 R M S}}{Z_{R M S}}=\frac{\sqrt{\frac{1}{T} \cdot \int_{t}^{t+T} x_{2}(t)^{2} d t}}{\sqrt{\frac{1}{T} \int_{t}^{t+T} z(t)^{2} d t}}
\end{gathered}
$$

The rms values of the remaining quantities were derived according to equation (5).

$$
\theta=\sqrt{\frac{1}{T} \cdot \int_{t}^{t+T} \theta(t)^{2} d t}
$$

The experimental results are compiled in the form of frequency characteristics in figures 6-14. Introduced the following notation of investigated systems: PS - passive system, SP - self-powered system, SP MGS - self-powered system with a Graetz bridge, SP C1, SP C2 - self-powered system with a bipolar condenser.

When no power supply is provided to the coil in the damper MR1 (PS), the transmissibility plots $T_{x 1 z}$ and $T_{x 2 z}$ for the predetermined current levels $I_{2}=0.1 \mathrm{~A}$ and $I_{2}=0.3 \mathrm{~A}$ (figures 6 and 7) reveal a single maximum for the resonance frequency $f_{r}$. For current $I_{2}=0.3 \mathrm{~A}$ the values of the transmissibility coefficient $T_{x 1 z}$ and $T_{x 2 z}$ for the resonance frequency $f_{r}=4.5 \mathrm{~Hz}$ are identical and equal to 2.35 . When $I_{2}=0.1 \mathrm{~A}$, the values of the transmissibility ratio in resonance are different and so is the frequency at which the maximum is registered $\left(T_{x 1 z}=1.32, f_{r}=4.5 \mathrm{~Hz}, T_{x 2 z}=1.25\right.$, $f_{r}=4.24 \mathrm{~Hz}$ ). A performance analysis of the vibration reduction system with the energy recovery capability involves two stages. In the first stage the 2DOF mechanical application is considered in which the current level in the MR2 damper coil was $I_{2}=0.1 \mathrm{~A}$; in stage two the current level was $I_{2}=0.3 \mathrm{~A}$. This approach reveals how the energy conditioning system should affect the characteristics of this application for values of two damping levels between the objects whose masses are $m_{1}$ and $m_{2}$.

In relation to the passive system (PS), when the coil in the MR1 damper is directly supplied with recovered vibration energy (SP), the value of the transmissibility coefficient $T_{x 1 z}$ is reduced in the frequency range $4-8.75 \mathrm{~Hz}$, in the case of $T_{x 2 z}$ the frequency range is $4-10 \mathrm{~Hz}$. In the other frequency intervals, the values of these two coefficients are higher, which fully justifies the use of the energy conditioning system to further decrease their value. In relation to the US system, usage of the Graetz bridge (SP MGS) brings about the decrease of $T_{x 1 z}$ in the frequency range 2-14 Hz, but it increases at frequencies in excess of $14 \mathrm{~Hz}$. In the case of the two systems, the values of $T_{x 2 z}$ are similar except at near-resonance frequencies $(2-4.25 \mathrm{~Hz})$ and at frequencies higher than $14 \mathrm{~Hz}$. The system SP C1 causes the values of $T_{x 1 z}$ and $T_{x 2 z}$ to decrease in the entire frequency range (while compared to the SP system) or for frequencies below $13 \mathrm{~Hz}$ (for the system PS). Besides, this system ensures the most effective vibration reduction at near-resonance frequencies $(2-6 \mathrm{~Hz})$. In the frequency range $6.25-13 \mathrm{~Hz}$ the lowest values of $T_{x 1 z}$ are achieved when the system SP C2 is used. Its major drawback, however, is that the values of $T_{x 1 z}$ and $T_{x 2 z}$ tend to increase at near-resonance frequencies (2-6 $\mathrm{Hz}$ ). In the case of all of the studied systems, the rms value of force $F_{T 1}$ of the damper MR1 (fig. 8a) tends to increase with frequency. The greatest values of $F_{T 1}$ are re-gistered in the system SP MGS and the lowest- in PS. As regards to the voltage generated by EPE (fig. 10a), it tends to increase with frequency, except in the system US C2 in which voltage slightly decreases at frequencies in excess of $13 \mathrm{~Hz}$. 
a)

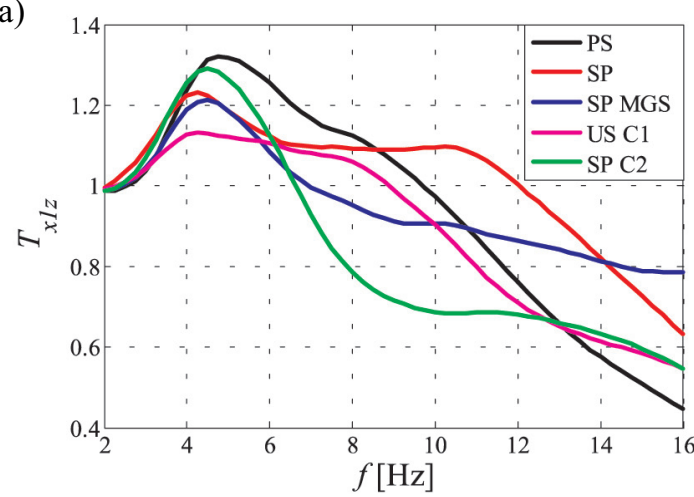

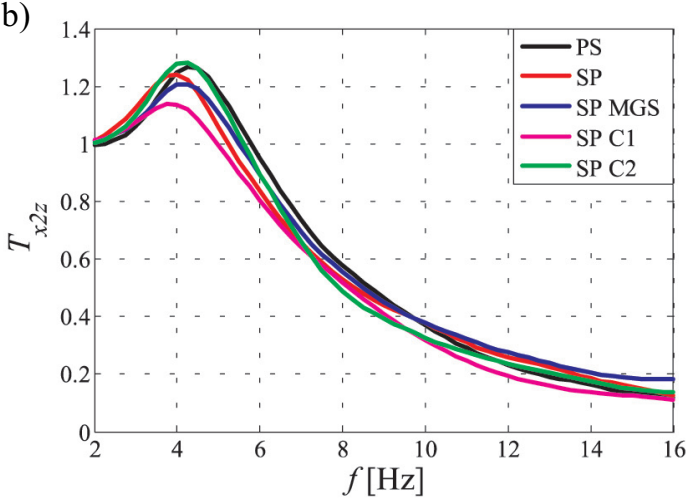

Fig. 6. Transmissibility coefficients for $I_{2}=0.1 \mathrm{~A}$ : a) $T_{x 1 z}$, b) $T_{x 2 z}$

a)

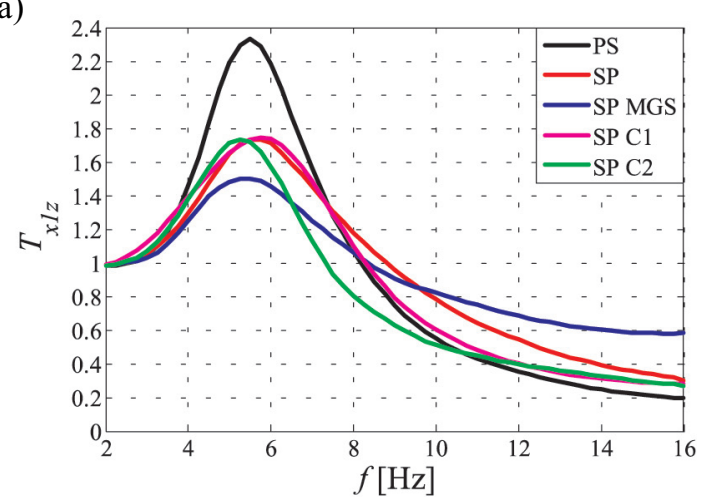

b)

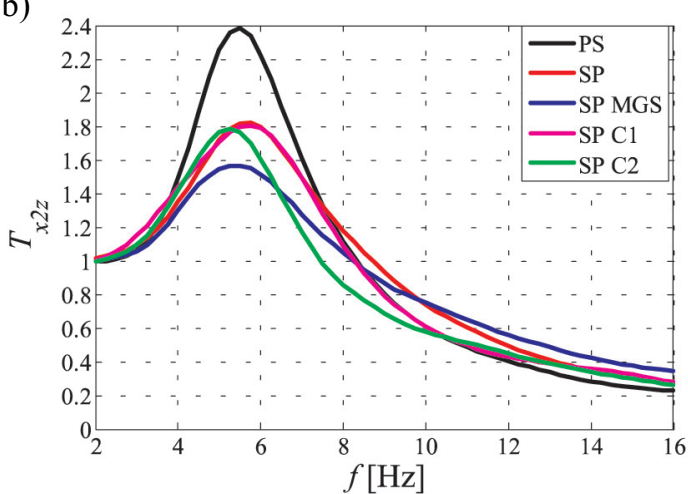

Fig. 7. Transmissibility coefficients for $I_{2}=0.3$ A: a) $T_{x 1 z}$, b) $T_{x 2 z}$

a)

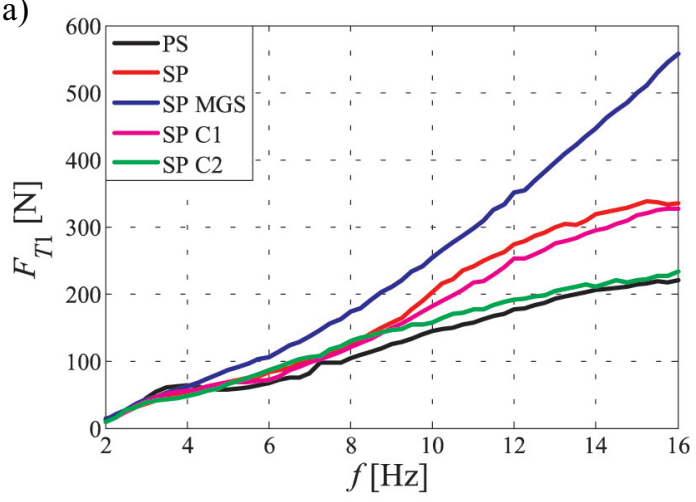

b)

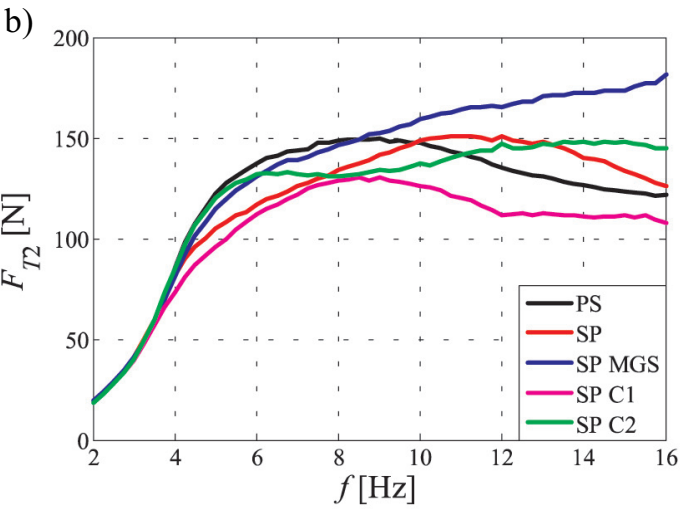

Fig. 8. Rms value of the damping force for $I_{2}=0.1$ A: a) $F_{T 1}$, b) $F_{T 2}$

a)

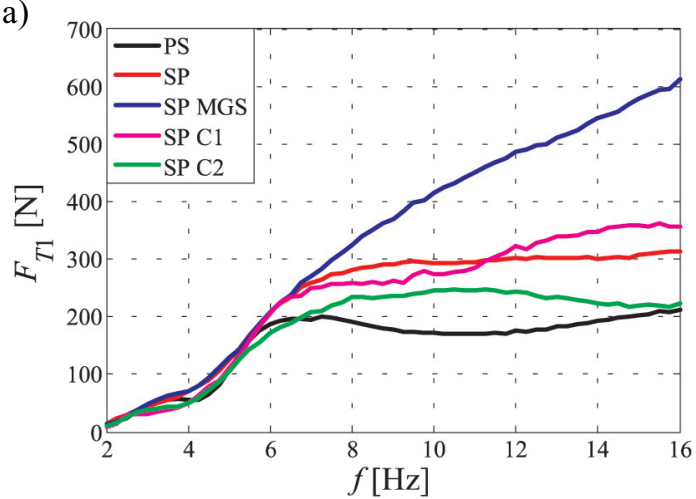

b)

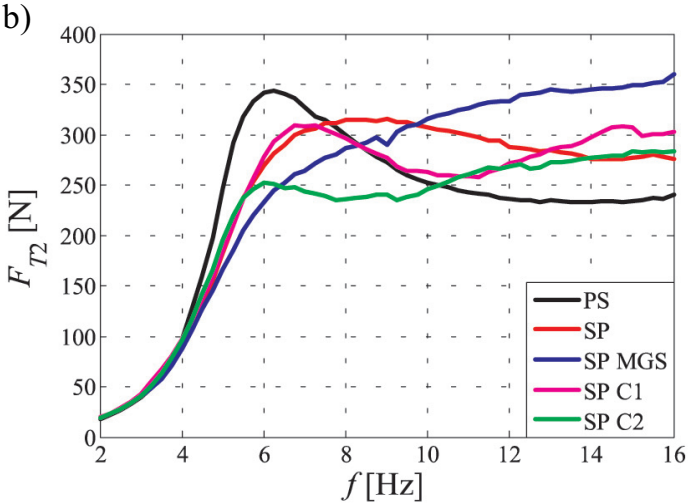

Fig. 9. Rms value of the damping force for $I_{2}=0.3 \mathrm{~A}$ : a) $F_{T 1}$, b) $F_{T 2}$ 
a)

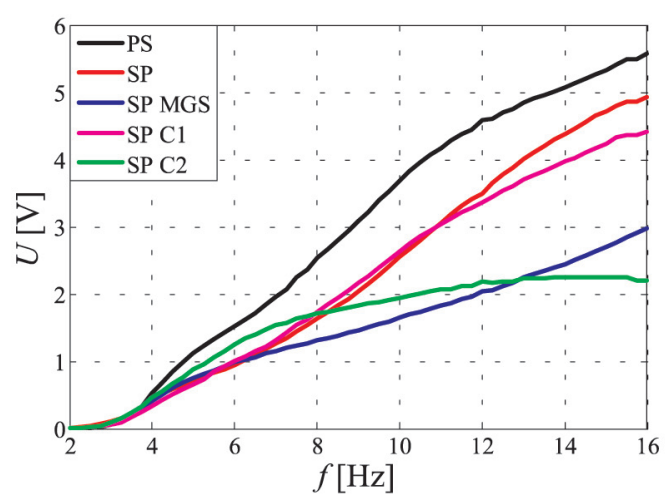

b)

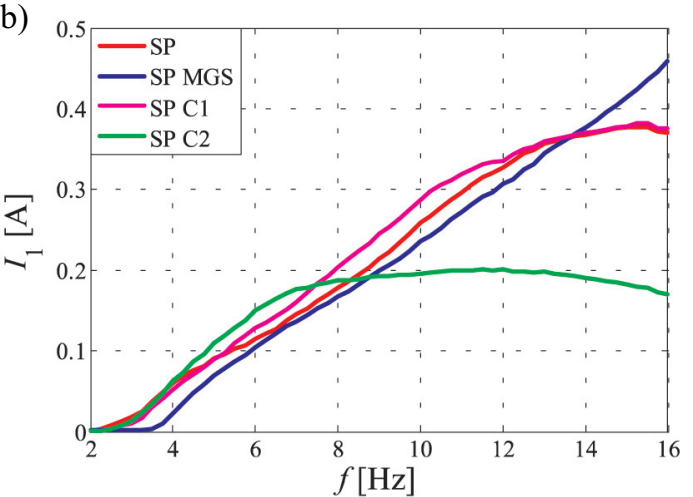

Fig. 10. Rms value of voltage and current intensity for $I_{2}=0.1 \mathrm{~A}$ : a) $U$, b) $I_{1}$

a)

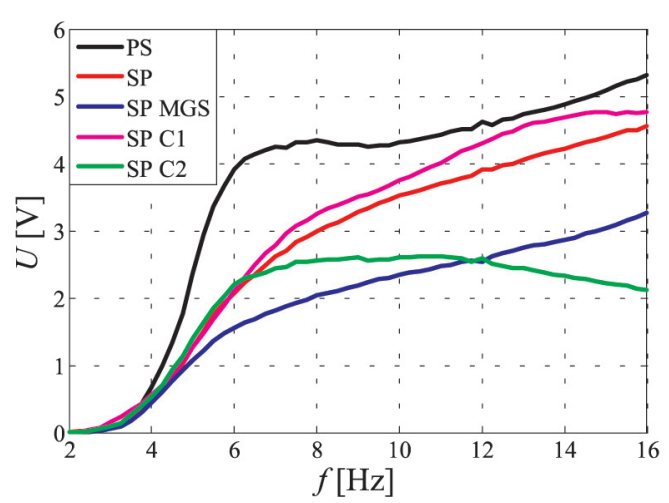

b)

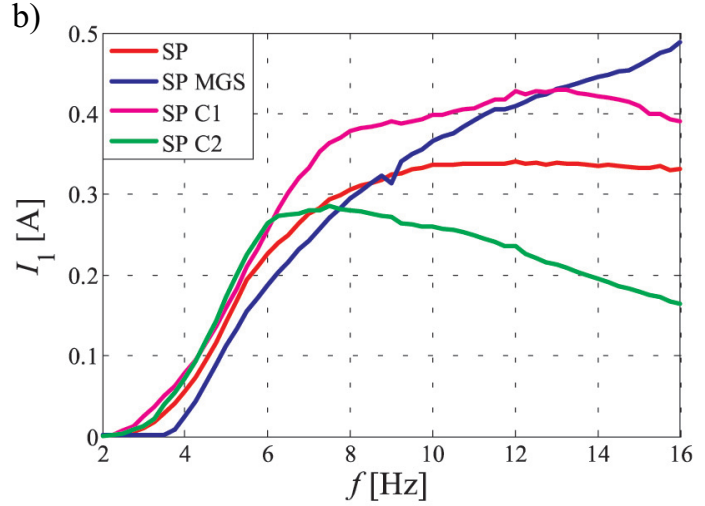

Fig. 11. Rms value of voltage and current intensity for $I_{2}=0.3 \mathrm{~A}$ : a) $U$, b) $I_{1}$

a)

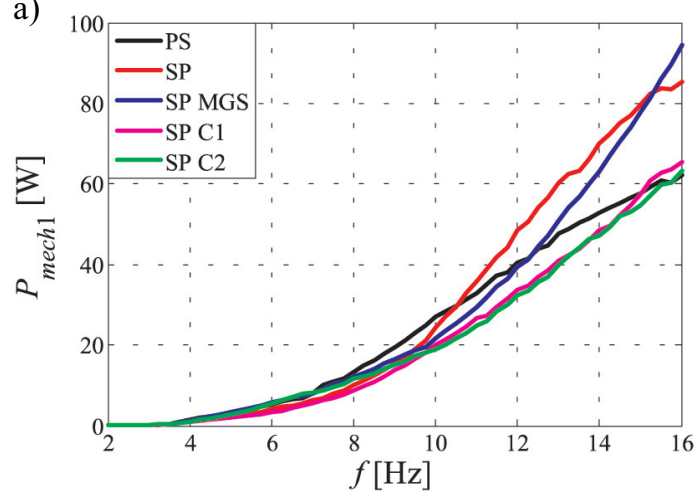

b)

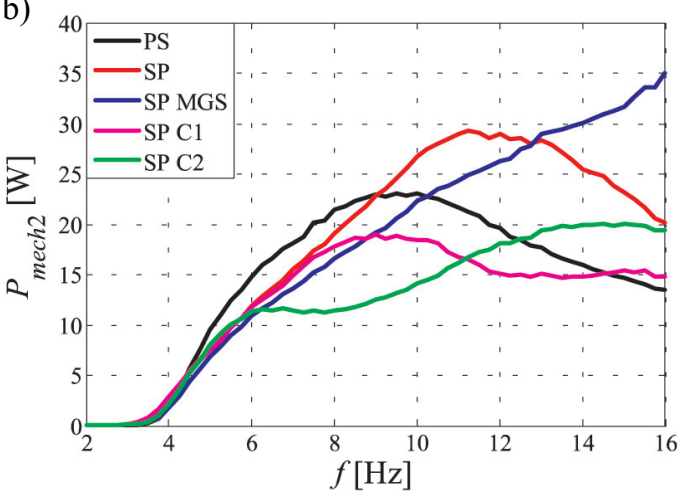

Fig. 12. Real power dissipated by the damper for $I_{2}=0.1$ A: a) $P_{\text {mech } 1}$, b) $P_{\text {mech } 2}$
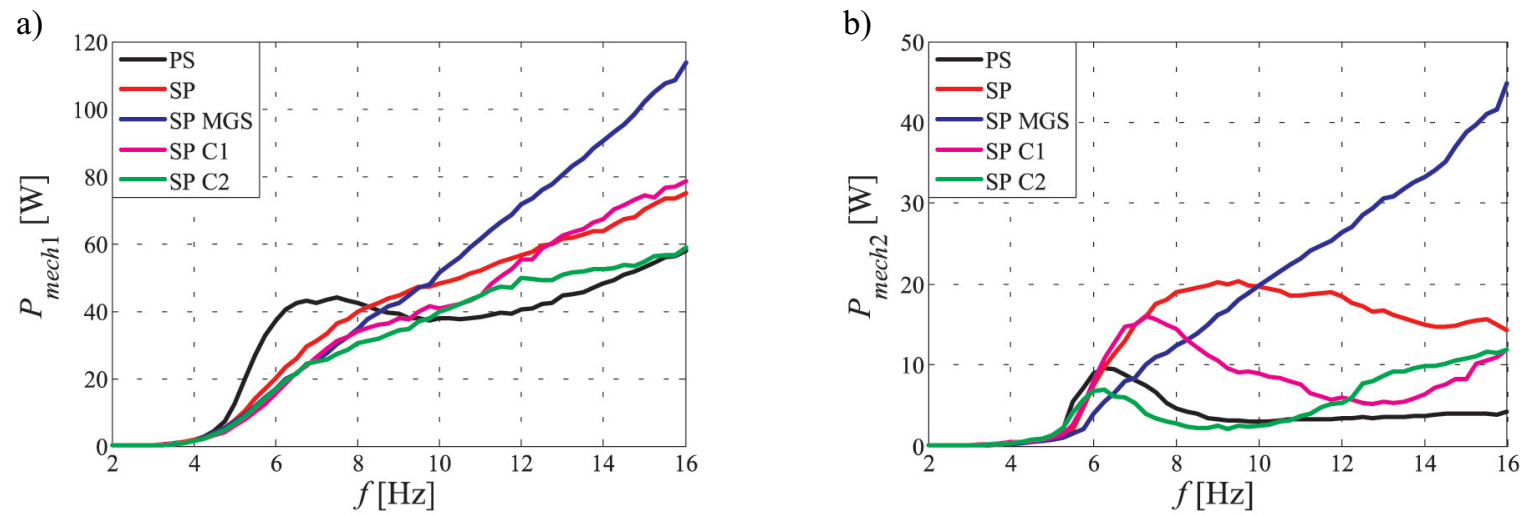

Fig. 13. Real power dissipated by the damper for $I_{2}=0.3$ A: a) $P_{\text {mech } 1}$, b) $P_{\text {mech } 2}$ 

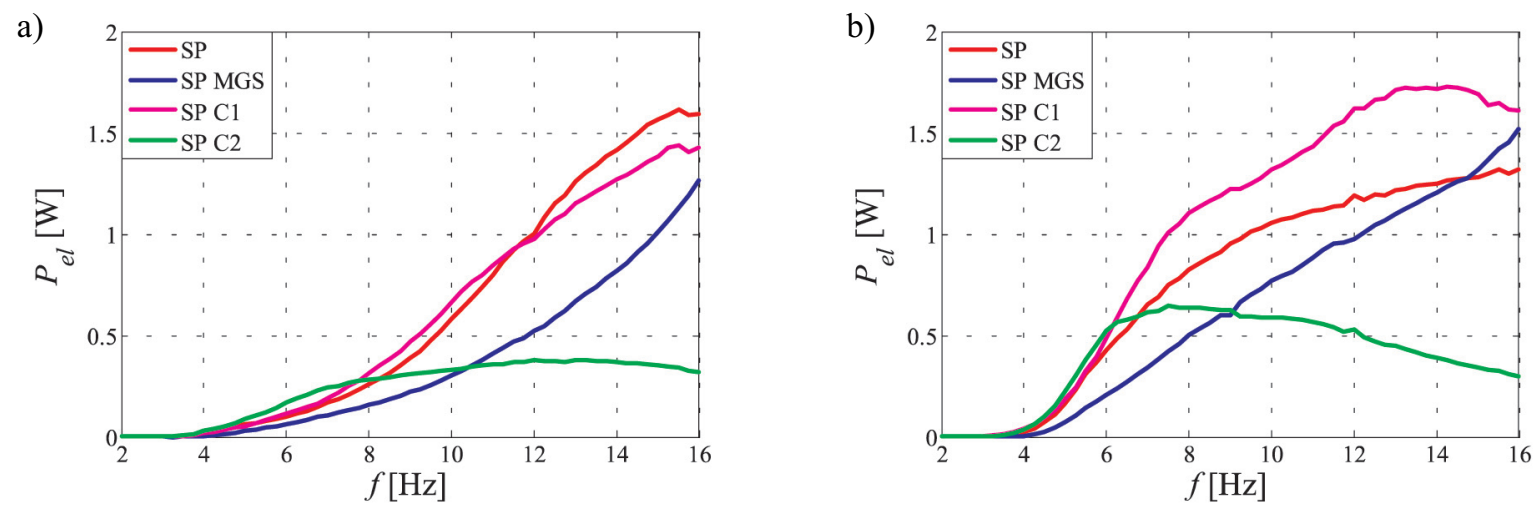

Fig. 14. Active power supplied by the transducer $P_{e l}$ for: a) $I_{2}=0.1 \mathrm{~A}$, b) $I_{2}=0.3 \mathrm{~A}$

The highest voltage levels $U$ are achieved in the system PS, that is so for two reasons. First, in this configuration the MR damper does not absorb energy from the EPE. Second, since the acting damping force $F_{T 1}$ is the lowest among the analysed systems, the motion velocity of the magnets' systems with respect to the EPE coil will significantly increase. The lowest voltages $U$ were registered for the system configurations SP MGS and SP C2, which can be attributed to the reduction of the motion velocity and a significant increase of current absorbed from EPE. Current intensity $I_{1}$ in the coil in the damper MR1 (fig. 10b) in the system configuration SP MGS is equal to 0 at frequencies below $3.5 \mathrm{~Hz}$. This effect may be caused by the forward voltage in diodes present in the Graetz bridge which tends to be higher than $0.4 \mathrm{~V}$ (fig. 10a) when the Shottky's diodes are used. Except for system configuration SP C2, a frequency increase is accompanied by an increase in the current $I_{1}$ for the analysed systems. At frequencies in excess of $14 \mathrm{~Hz}$, the current intensity $I_{1}$ is the highest in the system SP MGS, which is explained by increased levels of $T_{x 1 z}, T_{x 2 z}$ (fig. 6) in relation to SP. In the case of the system configuration SP C2 current intensity $I_{1}$ remained constant in the frequency range $7-12 \mathrm{~Hz}$ and for frequencies higher than $12 \mathrm{~Hz}$ in decreased slightly. Above $9 \mathrm{~Hz}$, it was the lowest among all of the analysed systems, which results in the lowest value of force $F_{T 1}$ among systems supplied via EPE in the frequency range 5-16 Hz. That explains the lowest values of $T_{x 1 z}$ in the frequency range $6.25-13 \mathrm{~Hz}$. When comparing system configurations SP C1 and SP, it appears that both voltage $U$ and current intensity $I_{1}$ have similar values and differences in $T_{x 1 z}$ revealed in figure 6a which can be attributed to different phase shifts between voltage $U$ and current $I$ (fig. $3 b$ ). An interesting feature can be observed when comparing the plots of mechanical power $P_{\text {mech } 1}$ dissipated by the damper MR1 (fig. 12a) with that of electric power $P_{e l}$ supplied to the damper MR1 (fig. 14a). In the case of the system configuration SP MGS electric power $P_{e l}$ is significantly lower than in SP or SP C1. At the same time the system SP MGS delivers mechanical power $P_{\text {mech } 1}$ comparable to that in SP and higher than that registered for SP C2 at frequencies in excess of $10 \mathrm{~Hz}$. It can be explained by analysing the plots of rms values of voltage $U$ and current $I_{1}$ (fig. 10) and of force $F_{T 1}$ (fig. 8a). At $16 \mathrm{~Hz}$ current $I_{1}$ in the system SP MGS reaches a decidedly higher value than for SP even though voltage $U$ is nearly twice as high. It is the consequence of the voltage being rectified by the conditioning system, as a result the average voltage value is nonzero. The voltage having a nonzero average value induces a higher intensity current in the damper coil than the voltage with the zero average value, which is the direct consequence of its dynamic properties (fig. 3a). Besides, the nonzero value of current intensity $I_{1}$ gives rise to higher rms values of damping force $F_{T 1}$ than when the alternating current is applied with the zero average value (fig. 8a), which can be attributable to the properties of MR fluids.

At near resonance frequencies $(2-7.5 \mathrm{~Hz})$ and for enhanced damping between the objects with the masses $m_{1}$ and $m_{2}\left(I_{2}=0.3 \mathrm{~A}\right)$ direct supply of recovered energy from EPE to the coil in a MR1 damper leads to a reduction of $T_{x 1 z}$ and $T_{x 2 z}$ in relation to the system configuration PS (fig. 7). At the same time the values of these coefficients would increase at frequencies exceeding $7.5 \mathrm{~Hz}$. In the system configuration SP MGS vibration in the near-resonance range is more effectively reduced; the main drawback being the enhanced level of vibration above the resonance frequency. After exceeding $10 \mathrm{~Hz}$, the transmissibility coefficients would reach the highest levels among the analysed system configurations. In the system SP C1 vibration reduction in the near-resonance range is as effective as in SP. For frequencies exceeding $7.5 \mathrm{~Hz}$, the values of $T_{x 1 z}$ and $T_{x 2 z}$ are similar to those registered in the system PS, which is a major advantage. In relation to the system configurations SP C1, the system SP C2 further reduces the vibration in the frequency range 5-12 Hz. The largest values of the damping force $F_{T 1}$ (fig. 9a) among the analysed systems were registered in SP MGS, the lowest- in the system PS. In the near resonance range the largest damping force $F_{T 2}$ (fig. 9b) was registered in the system PS, the lowest- in SP MGS. At frequencies higher than $10 \mathrm{~Hz}$, the pattern of the system's behaviour is reversed. Increased vibration frequencies leads to an increase in voltage $U$ (fig. 11a) generated by EPE in all system configurations except US C2, 
where it tends to decrease at frequencies higher than $10 \mathrm{~Hz}$. For the system configuration SP MGS the current intensity $I_{1}$ (fig. 11b) would increase with frequency in its entire range, whilst in the other systems it would decrease at frequencies higher than $12 \mathrm{~Hz}$ in SP and SP C1 and $7.5 \mathrm{~Hz}$ in SP C2. In SP MGS the current value was zero up to frequency $3.5 \mathrm{~Hz}$, which is attributable to the forward voltage in diodes. At maximal frequency $16 \mathrm{~Hz}$, the largest current level $I_{1}$ is registered in US MGS, the lowest - in US C2. At frequencies higher than $10 \mathrm{~Hz}$, the damper MR1 incorporated in US MGS has the highest power $P_{\text {mech } 1}$ (fig. 13a) among the analysed system configurations, though at frequencies from the range $4-15 \mathrm{~Hz}$, the values of electric power $P_{e l}$ (fig. 14b) are lower than in systems SP, SP C1. These observations seem to prove the fact that supplying the damper coil with voltage with nonzero average value gives rise to an increase of current and force, while compared to voltage with identical rms value but with zero average value.

\section{SUMMARY}

The study summarises the results of investigations of a 2DOF mechanical application with the implemented vibration reduction system with energy recovery and conditioning capability. It is demonstrated that the application of a conditioning system causes the frequency vs transmissibility characteristics to be significantly changed. The first purpose of the conditioning systems is to reduce the vibration of the mechanical application in the frequency range as wide as possible. The conditioning system incorporating a Graetz bridge (SP MGS) ensures the most effective vibration reduction in the near resonance range among the tested systems. Its major drawback, however, is a significant increase of vibration levels at frequencies higher than the resonance frequency. Coefficients $T_{x 1 z}$ and $T_{x 2 z}$ reach the highest value in the system SP MGS, at frequencies in excess of $14 \mathrm{~Hz}\left(I_{2}=0.1 \mathrm{~A}\right)$ and $10 \mathrm{~Hz}\left(I_{2}=0.3 \mathrm{~A}\right)$. Application of the system SP C1 allows for vibration reduction throughout the tested frequency range for two considered damping levels between the objects with the masses $m_{1}$ and $m_{2}$. When compared to SP C1, the system SP C2 effected vibration reduction as long as the MR2 damper coil was supplied with current with intensity $I_{2}=0.3 \mathrm{~A}$. When $I_{2}=0.1 \mathrm{~A}$, the system SP C2 at near-resonance frequencies would enhance vibration. Tests show that for low damping levels between the objects with the masses $m_{1}$ and $m_{2}$ $\left(I_{2}=0.1\right)$, the system SP C1 performs best, whilst for higher damping levels $\left(I_{2}=0.3 \mathrm{~A}\right)$, the system SP C2 proves to be most effective.

This study was sponsored through the AGH University of Science and Technology under research program No. 11.11.130.958.

\section{References}

Analog Devices, 2015, http://www.analog.com.

Brüel \& Kjær, 2015, http://www.bksv.com.

Cho S.W., Jung H.J., Lee I.W., 2005, Smart passive system based on a magnetorheological dampers. Smart Materials and Structures, 1, pp. 707-714

Cho S.W., Jung H.J., Lee I.W., 2007, Feasibility Study of Smart Passive Control System Equipped with Electromagnetic Induction Device. Smart Materials and Structures 16, pp. 2323-2329.

Emsyst, 2015, http://www.emsyst.sk.

Inteco, 2015, http://www.inteco.com.pl.

Jastrzębski Ł., 2014, Układy redukcji drgań z tlumikami magnetoreologicznymi i elektromechanicznymi przetwornikami energii. Rozprawa doktorska - Akademia Górniczo-Hutnicza, Kraków.

National Instruments, 2015, http://www.ni.com.

PCB Piezotronics, 2015, http://www.pcb.com.

Sapiński B., 2011, Experimental study of a self-powered and sensing MR-damper-based vibration control system. Smart Materials and Structures, 20(10), 105007.

Sapiński B., 2014, Energy harvesting MR linear damper: prototyping and testing. Smart Materials and Structures, 23(3), 035021.

Sapiński B., Rosół M., Jastrzębski Ł., 2011a, Charakterystyki semiaktywnego ukladu redukcji drgań z odzyskiem energii. Pomiary, Automatyka, Kontrola, vol. 57, no. 5, pp. 502-506,

Sapiński B., Rosół M., Jastrzębski Ł., 2011b, Badania laboratoryjne modelu semiaktywnego zawieszenia z odzyskiem energii. Pomiary, Automatyka, Robotyka, vol. 15, no. 11, pp. 68-73.

SensoPart, 2015, http://www.sensopart.com.

Snamina J., Sapiński B., 2011, Energy balance in self-powered MR damper-based vibration reduction system. Bulletin of the Polish Academy of Sciences - Technical Sciences, vol. 59, iss. 1, pp. 75-80. 